\title{
Profil Analisis Kebutuhan Modul Ajar pada Perkuliahan Model Pembelajaran IPA di SD Bagi Mahasiswa Pendidikan Guru Sekolah Dasar
}

\author{
Helmi ${ }^{1}$, Afridha Sesrita ${ }^{2}$, Sobrul Laeli ${ }^{3}$ \\ 1,2Program Studi Pendidikan Guru Sekolah Dasar Fkip Universitas Djuanda Bogor \\ ${ }^{3}$ Program Studi Pendidikan Agama Islam Fkip Universitas Djuanda Bogor \\ *Email: helmia.suwarjono@gmail.com
}

\begin{abstract}
Abstrak
Model pembelajaran IPA di sekolah dasar merupakan salah satu mata kuliah yang membekalkan keterampilan dasar bagi seorang calon guru yang meliputi berbagai model pembelajaran IPA yang diterapkan disekolah dasar. Pada kenyataanya ada banyak hambatan dalam proses pembelajaran. Karenanya dilakukan berbagai upaya untuk mendapatkan hasil yang optimal dalam perkuliahan ini sehingga setiap mahasiswa yang mengikuti perkuliahan dapat mengaplikasikan ilmunya dengan bekal yang cukup. Penelitian ini merupakan langkah perbaikan sistem perkuliahan yaitu perbaikan bahan ajar yang digunakan. Tahap awal yang dilakukan adalah menganalisis kebutuhan modul yang diperlukan oleh mahasiswa meliputi perlu dan tidaknya modul dibuat, bentuk modul yang diharapkan, cakupan isi dan sebagainya. Subjek penelitian adalah mahasiswa PGSD di Universitas djuanda Bogor $(\mathrm{N}=30)$ dengan menyebarkan angket yang mencakup tingkat pemahaman materi dan analisis kebutuhan modul. Berdasarkan data dari angket, didapatkan bahwa penguasaan mahasiswa terhadap materi masih tergolong rendah, sedangkan modul yang memenuhi kriteria baik, menarik dan memudahkan pembelajaran sangat dibutuhkan oleh mahasiswa.
\end{abstract}

Kata kunci: Modul Ajar, Analisis Kebutuhan, Pendidikan IPA SD

\section{PENDAHULUAN}

Perkuliahan model pembelajaran IPA di SD merupakan mata kuliah wajib pada jurusan Pendidikan Guru Sekolah Dasar (PGSD) di Universitas Djuanda Bogor. Mata kuliah ini memiliki beban 3 SKS diberikan pada semester 4 (empat). Pembelajaran IPA di SD adalah pondasi awal dalam terciptanya siswa-siswa yang mempunyai ilmu pengetahuan, keterampilan serta sikap ilmiah. Pendidikan IImu Pengetahuan Alam diarahkan melalui cara mencari tahu tentang alam secara sistematis, sehingga IImu Pengetahuan Alam (IPA) tidak saja merupakan kegiatan penguasaan sekumpulan ilmu pengetahuan yang berbentuk fakta-fakta, konsep-konsep, atau prinsip-prinsip saja, akan tetapi juga merupakan suatu proses penemuan dan pembentukan sikap ilmiah (Tursinawati, 2013).Melihat pentingnya mata kuliah ini dikuasai oleh mahasiswa, maka dilakukan upaya untuk terus-menerus memberikan inovasi agar penguasan mahasiswa terhadap materi yang diajarkan pada mata kuliah ini semakin meningkat.

Mata kuliah ini berfokus pada bagaimana kemampuan mahasiswa dalam menguasai model pembelajaran IPA di Sekolah Dasar. Secara umum IPA meliputi tiga bidang ilmu dasar, yaitu biologi, fisika, dan kimia. IPA adalah ilmu yang tercetus dan berkembang melalui kegiatan observasi, perumusan masalah, perumusan hipotesis, pengujian hipotesis dan eksperimen, penyimpulan, serta penyatuan teori dan juga konsep. Oleh karenanya, IPA membangkitkan minat dan keinginan untuk meningkatkan kecerdasan dan pemahamannya tentang alam seisinya yang penuh dengan ilmu pengetahuan yang tidak ada akhirnya.Model pembelajaran merupakan alat yang sistematis yang memungkinkan guru untuk memvariasikan praktik pedagogik kelas mereka untuk memenuhi kebutuhan semua peserta didik di kelas mereka (Nordyke, 2011)

Modul perkuliahan adalah acuan pembelajaran yang paling penting disamping kurikulum dalam pembelajaran. Yarmaidi (2003) menyampaikan bahwa keberadaan buku ajar serta media pembelajaran akan sangat membantu dalam meningkatkan pemahaman dan prestasi mahasiswa pada pembelajaran. Dalam memahami materi suatu pembelajaran, diperlukan panduan yang jelas dan utuh untuk dapat mahasiswa menguasai dengan mudah. Oleh karena itu bahan ajar adalah 
bagian yang juga sangat penting dalam pelaksanaan perkuliahan di perguruan tinggi. Modul ajar menjadikan mahasiswa bisa belajar suatu kompetensi dengan benar dan sistematissehingga secara umum dapat menguasai semua kompetensi dengan utuh dan inegrated (Panggabean, 2015). Lebih lanjut, urgensi bahan ajar dalam suatu perkuliahan dijelaskan oleh (Dimas.dkk, 2016) yang menyatakan bahwa bahan ajar adalah juga faktor eksternal untuk peserta didik yang mampu menguatkan motivasi dari dalam dirinya untuk dapat memeahami sebuah materi pembelajaran

Semua bahan yang disusun secara sistematis yang menampilkan sosok utuh dari kompetensi yang akan dikuasai peserta didik dan digunakan dalam proses pembelajaran dengan tujuan perencanaan dan juga sebuah penelaahan implementasi pembelajaran disebut bahan ajar (Andi, 2012). Bahan ajar yang kerap digunakan dalam perkuliahan adalah modul perkuliahan. Modul dibuat mengacu kepada tujuan perkuliahan yang termaktub dalam kurikulum pada sebuah mata kuliah.Beberapa keunggulan pembelajaran yang memanfaatkan media modul perkuliahan yaitu:modul menitikberatkan pada kemampuan untuk bekerja sendiri dan lebih bertanggung jawab atas segala tindakan, modul menjadi kontrol bagi setiap hasil belajar melalui penggunaan standar kompetensi dalam pada tiap modul yang harus dicapai peserta didik, modul sendiri memiliki relevansi dengan kurikulum yang dapat ditunjukkan dengan adanya tujuan dan cara pencapaiannya sehingga peserta didik dapat mengetahui keterkaitan antara pembelajaran dan hasil yang akan diperoleh (Mulyasa, 2006). Menurut BSNP (dalam Muslich, 2010) sebuah bahan ajar dapat disebut layak jika dapat memenuhi empathal yaitu komponen kelayakan isi, komponen kelayakan kebahasaan, komponen kelayakan penyajian, dan komponen kelayakan kegrafikan.

\section{METODE}

Penelitian ini adalah penelitian deskriptif kualitatif yang berfokus pada analisis kebutuhan mahasiswa akan bahan ajar pada perkuliahan model pembelajaran IPA di SD, analisis kebutuhan meliputi tingkat seberapa penting/butuhnya mahasiswa akan bahan ajar, urgensi atau tidaknya keberadaan bahan ajar dalam kegiatan perkuliahan model pembelajaran IPA di SD, seberapa dalam pengetahuan mahasiswa akan bentuk dan penggunaan bahan ajar, bahan ajar seperti apa yang sebetulnya diperlukan oleh mahasiswa, dan lain sebagainya. Subjek dalam penelitian ini adalah mahasiswa calon guru sekolah dasar di fakultas keguruan dan ilmu pendidikan universitas Djuanda Bogor semester 4 yang telah menempuh mata kuliah model pembelajaran IPA di disekolah dasar $(\mathrm{N}=30)$. Pengumpulan data dilakukan dengan observasi, angket terbuka dan wawancara.

\section{HASIL DAN PEMBAHASAN}

Berdasarkan hasil wawancara dan observasi, selama ini dosen pengampu mata kuliah memberikan perkuliahan dengan bantuan slidepowerpoint, diskusi dan presentasi oleh mahasiswa. Sedangkan bahan ajar yang diberikan adalah dalam bentuk cetak/print out slide powerpoint yang diberikan ketika perkuliahan berlangsung. Dosen pengampu mata kuliah menyetujui untuk diadakanya modul ajar yang sesuai dengan karakteristik dan kebutuhan mahasiswa. Sehingga dilakukan pada tahap awal yaitu analisis kebutuhan melalui penyebaran angket kepada mahasiswa. Angket yang disebar kepada mahasiswa kemudian dianalisis data hasilnya. hasil analisis disajikan dalam bentuk grafik analisis kebutuhan. berdasarkan data yang diperoleh melalui angket, didapati bahwa selama ini bahwa perkuliahan menggunakan powerpoint yang berupa file dan printout. Sebagian besar mahasiswa program studi pendidikan guru sekolah dasar (PGSD) tidak memiliki modul yang terstandar. bahan ajar yang digunakan adalah print out powerpoint dan buku sumber yang dibeli oleh masing-masing mahasiswa yang membutuhkan. modul yang digunakan selama ini tidak memenuhi harapan dari mahasiswa pengguna. data angket yang dikumpulkan dapat dilihat 
pada uraian berikut ini:

Berdasarkan data yang diperoleh tentang analisis capaian materi dan penguasaan konsep mahasiswa jurusan pendidikan guru sekolah dasar pada perkuliahan model pembelajaran IPA di SD adalah sebagai berikut:

secara keseluruhan mahasiswa masih kesulitan memahami materi model pembelajaran IPA di sekolah dasar (70\%), 62\% mengatakan bahwa materi yang paling sulit untuk dipelajari adalah model pembelajaran Siklus belajar, hal ini dikarenakan tahapan yang dilakukan dalam model pembelajaran ini baru dikenalkan kepada mahasiswa. Materi model pembelajaran Inquiry adalah yang paling mudah untuk dipelajari dan diterapkan $(80 \%)$, penyebabnya adalah karena model Inquiry hampir selalu diulang-ulang oleh guru dalam kegiatan pembelajaran sains. dalam hal ini, dapat disimpulkan bahwa pengulangan yang terus menerus akan memberikan kemudahan mahasiswa dalam mempelajarai suatu materi tertentu. 55\% mahasiswa menyatakan bahwa metode pembelajaran yang selama ini digunakan tidak menarik, $78 \%$ mengharapkan pembelajaran yang lebih konkrit. Secara lebih jelas dapat dilihat pada bagan 1 :

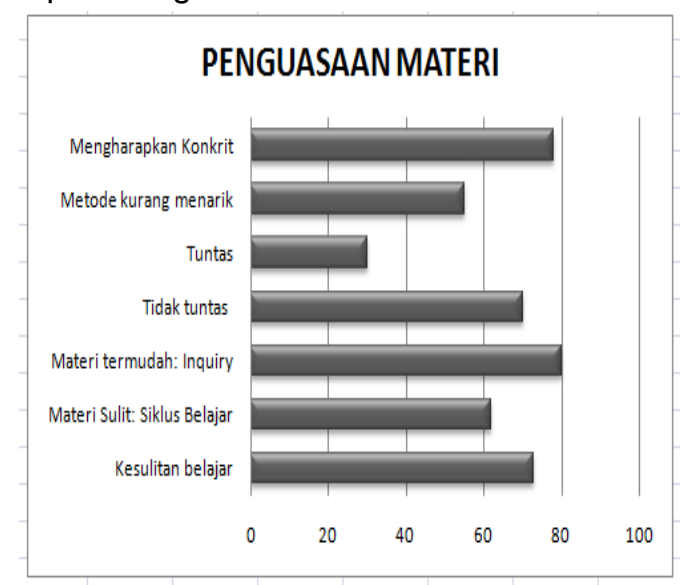

Bagan 1. Chart Penguasaan Konsep

Sedangkan soal angket mahasiswa berkenaan dengan kebutuhan pengembangan modul adalah sebagai berikut :

1. Dalam kegiatan perkuliahan dalam kelas, metode apa yang paling sering digunakan dosen untuk mengajarkan mata kuliah model pembelajaran IPA SD?

2. Sumber belajar berbentuk apa saja yang Saudara/i gunakan dalam pembelajaran?

3. Jika Saudara/i menggunakan buku cetak, berapa jumlah buku cetak yang Saudara/i gunakan dalam pembelajaran?

4. Apakah anda pernah menggunakan modul sebagai sumber/bahan dalam belajar?

5. Apakah buku sumber IPA yang digunakan sudah membantu memahami materi perkuliahan?

6. Apakah modul dalam perkuliahan harus menarik?

7. Perlukah modul perkuliahan model pembelajaran IPA SD memuat ilustrasi disetiap model pembelajaran yang di sampaikan dalam materi?

Hasil yang diperoleh dari angket yang diberikan kepada mahasiswa mengenai respon mahasiswa terhadap penggunaan modul ajar yang digunakan didalam perkuliahan terlihat pada tabel 1 dibawah ini 
Tabel 1. Respon mahasiswa

\begin{tabular}{|c|c|c|c|}
\hline No & \multicolumn{3}{|c|}{ Respon } \\
\hline \multirow{2}{*}{$\mathbf{n y y}$} & Ceramah & Inquiry & Lainya \\
\cline { 2 - 4 } & $40 \%$ & $30 \%$ & $30 \%$ \\
\hline \multirow{2}{*}{$\mathbf{2}$} & Cetak & Elektronik & Lainya \\
\cline { 2 - 4 } & $20 \%$ & $75 \%$ & $5 \%$ \\
\hline \multirow{2}{*}{3} & Satu & $2-5$ & $>5$ \\
\cline { 2 - 4 } & $23 \%$ & $54 \%$ & $33 \%$ \\
\hline \multirow{2}{*}{$\mathbf{4}$} & Ya & \multicolumn{2}{|c|}{ Tidak } \\
\cline { 2 - 4 } & $100 \%$ & \multicolumn{2}{|c|}{-} \\
\hline \multirow{2}{*}{$\mathbf{5}$} & Ya & \multicolumn{2}{|c|}{ Belum } \\
\cline { 2 - 3 } & $22 \%$ & \multicolumn{2}{|c|}{$78 \%$} \\
\hline \multirow{2}{*}{$\mathbf{6}$} & Harus & \multicolumn{2}{|c|}{ Tidak harus } \\
\cline { 2 - 4 } & 100 & \multicolumn{2}{|c}{-} \\
\hline \multirow{2}{*}{$\mathbf{7}$} & Perlu & \multicolumn{2}{|c|}{ Tidak Perlu } \\
\cline { 2 - 4 } & $72 \%$ & \multicolumn{2}{|c}{$28 \%$} \\
\hline
\end{tabular}

Pada tabel 1 dapat dilihat bahwa metode perkuliahan yang digunakan masih cenderung kepada ceramah meskipun di match dengan metode lainya, pada umumnya mahasiswa mendapatkan materi perkuliahan dari sumber berbentuk elektronik, ketertarikan mahasiswa terhadap bacaan cukup tinggi dengan dibuktikanya dari hasil data yang diperoleh bahwa sekitar 87\% (54 dan 33) mahasiswa memiliki buku sumber. Hal yang cukup baik dari data hasil sebaran angket adalah bahwa keseluruhan mahasiswa sudah pernah menggunakan modul dalam kegiatan perkuliahanya, meskipun harus dikaji lebih jauh apakah modul tersebut telah layak dan menarik bagi mahasiswa atau belum. Berdasarkan hasil analisis data, didapati bahwa buku sumber yang digunakan mahasiswa masih belum memudahkan pemahaman mahasiswa akan materi perkuliahan. Berdasarkan hasil yang didapatkan dari pengumpulan dan analisis data, dapat disimpulkan bahwa sangat diperlukan adanya pengembangan modul perkuliahan bagi mata kuliah model pembelajaran IPA di SD guna mempermudah pemahaman mahasiswa akan model-model pembelajaran IPA yang dapat diterapkan disekolah dasar.

\section{PENUTUP}

Berdasarkan hasil pengumpulan data, dapat disimpulkan bahwa mahasiswa mengharapkan modul perkuliahan yang menarik dalam pembelajaran yang diikutinya meskipun dapat dilihat bahwa dosen sebagai pegampu mata kuliah selama ini telah menggunakan modul dalam perkuliahanya. selain itu dalam penggunaan buku sumber, berdasarkan respon mahasiswa dapat dilihat bahwa buku sumber yang digunakan dalam perkuliahan maupun dalam pembuatan modul perlu mengalami perbaikan atau peningkatan. secara keseluruhan dapat disimpulkan bahwa kebutuhan mahasiswa akan modul adalah diharapkanya modul perkuliahan yang menarik, dari sumber yang beragam serta modul tersebut mudah dipahami. Melalui perolehan data hasil penelitian pendahuluan ini, semoga memberikan gambaran bagi pendidik IPA secara spesifik pendidik IPA SD, agar dapat menjadi salah satu acuan dalam perbaikan pelaksanaan pembelajaran yang dilakukan. selanjutnya diharapkan bahwa para peneliti dapat melanjutkan penelitian ini dengan riset yang mengarah pada pewujudan modul perkuliahan yang kaya isi, menarik dan mudah dipahami oleh mahasiswa sebagai penggunanya.

\section{UCAPAN TERIMAKASIH}

Ucapan terimakasih yang tak terhingga kami sampaikan kepada direktur riset dan pengabdian masyarakat, Direktorat jenderal penguatan riset dan pengembangan, Kementrian riset, 
tekhnologi dan pendidikan tinggi sesuai dengan surat perjanjian penugasan pelaksanaan hibah penelitian dipa nomor:1598/k4/km/2017 tahun anggaran 2017.

\section{DAFTAR PUSTAKA}

Andi, P. (2012). Panduan Kreatif Membuat Bahan Ajar Inovatif. Jogjakarta: Diva Press.

Dimas, A., Cari, C., Suparmi, A., Sarwanto, S., \& Handhika, J. (2017, January). Profil Analisis Kebutuhan Bahan Ajar Mahasiswa Materi Dinamika Gerak pada Mata Kuliah Fisika Dasar. In Prosiding SNFA (Seminar Nasional Fisika dan Aplikasinya) (Vol. 1, pp. 42-45).

Mulyasa, E. (2006). Kurikulum Berbasis Kompetensi. Bandung: Remaja Rosda Karya

Muslich, M. (2010). Text book writing. Yogyakarta: Ar-Ruzz Media.

Nordyke, A. M. (2011). Models of teaching: Indicators influencing teachers' perception of pedagogical choice. University of Southern California.

Panggabean, E. M. (2015). Pengembangan Bahan Ajar Dengan Strategi React Pada Mata Kuliah Struktur Aljabar I Di FKIP UMSU. EduTech: Jurnal IImu Pendidikan dan IImu Sosial, 1(01).

Tursinawati, T. (2013). Analisis Kemunculan Sikap IImiah Siswa Dalam Pelaksanaan Percobaan Pada Pembelajaran IPA di SDN Kota Banda Aceh. PIONIR: Jurnal Pendidikan, 1(1). 1-18

Yarmaidi. (2003). Penyediaan Buku Ajar dan Media Pengajaran Efektif serta Memperbanyak Contoh Soal Sebagai Upaya Meningkatkan Pemahaman dan Prestasi Mahasiswa Dalam Mata Kuliah Statistik IPS pada PS.P. Geografi Jurusan PIPS FKIP Universitas Lampung. Laporan Penelitian dalam Program peningkatan Efektifitas Pembelajaran di Kelas. Program Semi Que $\checkmark$ Tahun Universitas Lampung. 